\title{
REFORMULASI DISKRESI DALAM PENATAAN HUKUM ADMINISTRASI
}

(Reformulation Of Discretion In The Arrangement Administrative Law)

\author{
Arfan Faiz Muhlizi, S.H.,M.H. \\ Kepala Sub Bidang Fasilitasi Jabatan Fungsional Peneliti Hukum dan \\ Penelitian PUSLITBANG BPHN Kementerian Hukum dan HAM RI
}

\begin{abstract}
Abstrak
Instrumen hukum paling klasik untuk melaksanakan penyelenggaraan pemerintahan guna mewujudkan masyarakat yang adil dan makmur adalah Hukum Administrasi Negara (HAN). Untuk mencapai tujuan penyelenggaraan pemerintahan tersebut, birokrasi menjadi alat yang efektif didalam menjalankan pengelolaan negara. Persoalan hukum dari birokrasi yang menjadi permasalahan saat ini adalah persinggungan asas legalitas (wetmatigheid) dan diskresi (pouvoir discretionnaire) pejabat negara (eksekutif). Tulisan ini berusaha menjawab permasalahan di atas dengan lebih menitikberatkan bahasan mengenai "diskresi" dalam hukum administrasi. Dengan metode yuridis normative, penelitian ini menyimpulkan bahwa diskresi memang diperlukan dalam hukum administrasi, khususnya di dalam menyelesaikan persoalan dimana peraturan perundang-undangan belum mengaturnya atau hanya mengatur secara umum. Disamping itu diskresi juga diperlukan dalam hal terdapat prosedur yang tidak dapat diselesaikan menurut administrasi yang normal. Dengan demikian penataan Hukum Administrasi menjadi sangat penting dan tentunya bukan sekedar melihat dari sisi pembentukan atau penataan peraturan perundang-undangan terkait administrasi negara, tetapi lebih jauh dari itu adalah penataan tatanan hukum yang terdiri dari struktur, substansi, dan kultur masyarakat, birokrasi, dan penegak hukum.
\end{abstract}

Kata kunci: pemerintahan, administrasi, sistem, juridis, politis, legisme, rechtsvinding, kekuasaan, kewenangan, diskresi, kesejahteraan

\begin{abstract}
The most classical legal instruments to carry out government administration in order to realize a just and prosperous society is the Law of State Administration (HAN). To achieve the objectives of the government, the bureaucracy into an effective tool in the management of state run. Legal issues of bureaucracy which is the case today is the intersection of the principle of legality (wetmatigheid) and discretionary (pouvoir discretionnaire) state officials (executive). This article tries to answer the above problems with a more focused discussion on the "discretion" in administrative law. With normative juridical methods, the study concluded that discretion was necessary in administrative law, especially in solving problems in which the legislation has not been set or simply set in general. Besides, discretion is also required in case there are procedures that can not be resolved according to the normal administration. Thus the arrangement of Administrative Law to be very important and certainly not just a look from the side of the formation or arrangement of the legislation related to state administration, but further than that is the arrangement of the legal order which consists of the structure, substance, and the culture of the society, bureaucracy, and enforcement the law.
\end{abstract}

Keywords: governance, administration, systems, juridical, political, legisme, rechtsvinding, power, authority, discretion, welfare 


\section{A. Pendahuluan}

Kekuasaan yang mendapat dukungan politik sangat besar akan melahirkan Pemerintahan yang kuat (strong government). Dalam Negara kesejahteraan, pemerintahan yang kuat memang diperlukan dalam rangka membawa masyarakatnya menuju ke tingkat kesejahteraan yang lebih baik. Tetapi sejarah juga merekam bahwa Pemerintahan yang kuat juga berpotensi melahirkan perbuatan penyelenggara negara yang merugikan masyarakatnya dengan terjadinya penyalahgunaan kewenangan atau dilaksanakannya diskresi secara berlebihan.

Penyalahgunaan wewenang dalam konsephukumadministrasiselaludiparalelkan dengan konsep detournement de pouvoir. ${ }^{1}$ Dalam Verklarend Woordenboek Openbaar Bestuur dirumuskan sebagai: het oineignlijk gebruik makn van haar bevoegdheid door de overheid. Hirvan is sprake indien een overheidsorgaan zijn bevoegdheid kennelijk tot een order doel heeft gebruik dan tot doeleinen waartoe die bevoegdheid is gegeven. De overheid schendt aldus het specialiteitsbegensel yang diterjemahkan secarabebassebagai"penggunaanwewenang tidak sebagaimana mestinya". ${ }^{2}$ Dalam hal ini pejabat menggunakan wewenangnya untuk tujuan lain yang menyimpang dari tujuan yang telah diberikan kepada wewenang itu.
Gagasan tentang penyelenggaraan kekuasaan yang baik, dapat dilaksanakan melalui 2 (dua) pendekatan; personal dan sistem. Secara personal telah dimulai pada masa Plato. Menurut Plato ${ }^{3}$, penyelenggaraan kekuasaan yang ideal dilakukan secara paternalistik, yakni para penguasa yang bijaksana haruslah menempatkan diri selaku ayah yang baik lagi arif dalam tindakannya terhadap anak-anaknya sehingga terpadulah kasih dan ketegasan demi kebahagiaan anakanak itu sendiri. Pada bagian lain, Plato mengusulkan agar negara menjadi baik, harus dipimpin oleh seorang filosof, karena filosof adalah manusia yang arif bijaksana, menghargai kesusilaan, dan berpengetahuan tinggi. Tetapi murid Plato, Aristoteles, berpendapat bahwa pemegang kekuasaan haruslah orang yang takluk pada hukum, dan harus senantiasa diwarnai oleh penghargaan dan penghormatan terhadap kebebasan, kedewasaan dan kesamaan derajat. Hanya saja tidak mudah mencari pemimpin dengan kualitas pribadi yang sempurna.

Oleh karena itu, pendekatan sistem dengan bersandar pada hukum merupakan alternatif yang paling memungkinkan. Plato sendiri, di usia tuanya terpaksa mengubah gagasannya yang semula mengidealkan pemerintah itu dijalankan oleh raja-filosof menjadi pemerintahan yang dikendalikan

Philipus M. Hadjon, Kriminalisasi Perbuatan Administrasi Dalam Pemberantasan Tindak Pidana Korupsi, Makalah disampaikan dalam Continuing Legal Education BPHN Kementerian Hukum dan HAM pada tanggal 9 September 2009.

Ibid.

J.H. Harper, Filsafat Politik Plato, Aristoteles, Augustinus, Machiaveli, (Jakarta: PT Raja Grafindo Persada, 2002) hal. 54 . 
oleh hukum. Penyelenggaraan negara yang baik, menurut Plato, ialah yang didasarkan pada pengaturan hukum yang baik.

Berdasarkan pendapat Plato ini, maka penyelenggaraan pemerintahan yang didasarkan pada hukum merupakan salah satu alternatif yang baik dalam penyelenggaraan negara. Penyelenggaraan pemerintahan berdasarkan hukum ini sangat penting dalam rangka pembatasan kekuasaan guna menghindari kekuasaan yang absolut, karena akan menimbulkan kerusakan yang besar, sebagaimana pendapat Lord Acton, power tends to corrupt, absolute power corrupt absolutely. ${ }^{4}$ Kerusakan yang besar akibat absolutisme kekuasaan ini terjadi karena selalu ada nafsu untuk mempertahankan kekuasaan dengan berbagai cara, dan perilaku defensif akibat ketakutan kehilangan kekuasaan. Hal ini sebagaimana yang dikatakan Aung San Suu Kyi bahwa "It is not power that corrupts, but fear. Fear of losing power corrupts those who wield it, and fear of the scourge of power corrupts those who are subject to it." ${ }^{5}$

Pembatasan kekuasaan dengan
pengaturan secara hukum menuju
terwujudnya pemerintahan yang bersih

ini bisa dilakukan dengan dua mekanisme. Pertama, dengan menggunakan mekanisme check and balance 6 antara lembaga-lembaga negara dengan adanya pembagian kekuasaan, serta memberi ruang politik yang luas bagi hidupnya kelompok oposisi sebagai kekuatan pengontrol; Kedua, adalah mekanisme yuridis yang mengedepankan regulasi yang di antaranya melahirkan UU No. 28 Tahun 1999 tentang Penyelenggara Negara yang Bersih dan Bebas dari Korupsi, Kolusi, dan Nepotisme, (UU KKN) dan UU No. 31 Tahun 1999 tentang Pemberantasan Tindak Pidana Korupsi (UU TPK) yang kemudian diubah dengan UU No. 20 Tahun 2001 dan berbagai Hukum Administrasi Negara (HAN) yang di antaranya adalah UU No.5 Tahun 1986 tentang Peradilan Tata Usaha Negara sebagaimana diubah UU No.9 Tahun 2004 dan UU No.51 Tahun 2009. Mekanisme pertama dilakukan untuk mendapatkan keseimbangan dalam penyelenggaraan negara, sedangkan mekanisme kedua dilakukan untuk mendapatkan sebuah kepastian hukum.

Hukum Administrasi (HAN) merupakan instrumen hukum paling klasik untuk terselenggaranya pemerintahan yang baik. Penyelenggaraan pemerintahan lebih nyata

4 Dikutip dari Sri Soemantri Martosoewignjo, Undang-Undand Dasar 1945, Kedudukan dan Artinya Dalam Kehidupan Bernegara, Makalah disampaikan pada Stadium Generale dan 40 Tahun Pengabdiannya di Universitas Padjadjaran Bandung, 2001, hal. 7.

5 Kalimat ini dikutip dari statement Aung San Suu Kyi ketika dibebaskan oleh Rezim Militer Burma dari Penjara dan menjadi tahanan kota pada 2010. Lebih jauh lihat web resmi Piece Pledge Union di http://www.ppu.org.uk/ people/suukyi.html, bandingkan juga dengan http://chandrasway.blogspot.com/2010/12/aung-san-suu-kyi-iam-happy-because-i.html

Suprianto mengatakan bahwa "Tidak mungkin mengharapkan pemerintah sebagai suatu komponen dari proses politik memenuhi prinsip pemerintahan yang bersih apabila tidak memiliki moral, Proaktif serta check and balances. Lebih jauh lihat Suprianto, 2004, Syariat Islam dalam Mewujudkan "Clean Governance and Good Government" dalam www. transparansi.or.id. hal. 1. 
dalam HAN, karena di sini akan terlihat konkrit hubungan antara pemerintah dengan masyarakat, kualitas dari hubungan pemerintah dengan masyarakat inilah setidaknya dapat dijadikan ukuran apakah penyelenggaraan pemerintahan sudah baik atau belum. Di satu sisi HAN dapat dijadikan instrumen yuridis oleh pemerintah dalam rangka melakukan pengaturan, pelayanan, dan perlindungan bagi masyarakat, di sisi lain HAN memuat aturan normatif tentang bagaimana pemerintahan dijalankan, atau sebagaimana dikatakan Sjachran Basah, ${ }^{7}$ bahwa salah satu inti hakikat HAN adalah untuk memungkinkan administrasi negara menjalankan fungsinya, dan melindungi administrasi negara dari melakukan perbuatan yang salah menurut hukum.

Di sisi lain, dalam mengelola Negara perlu diingat bahwa penyelenggara negara bukan hanya berkewajiban untuk baik dan bersih dalam penyelenggaraan tugasnya mengelola negara, tetapi lebih dari itu adalah berkewajiban memenuhi tercapainya masyarakat yang adil dan makmur. Pemerintahan yang baik dan bersih bukanlah tujuan, melainkan sarana untuk mencapai tujuan. Artinya, pemerintahan yang bersih tidak akan bernilai apapun apabila tujuan ini tidak tercapai. Dengan demikian mekanisme juridis maupun politis di atas harus dibuat sedemikian rupa sehingga benar-benar mampu mendorong tercapainya tujuan dan bukan menghambat pencapaian tujuan.
Salah satu alat negara yang paling penting untuk mencapai tujuan itu adalah birokrasi. Untukitu birokrasi perlu dibangun sedemikian rupa sehingga menjadi baik dan mampu mendorong percepatan pencapaian tujuan. Pemerintahan yang bersih identik dengan birokrasi yang baik. Tetapi dalam membangun birokrasi yang bersih dengan mekanisme yuridis, salah satu persoalan hukum yang mengedepan adalah persinggungan asas legalitas yang mengutamakan kepastian hukum (wetmatigheid) dan diskresi (pouvoir discretionnaire) pejabat negara (eksekutif) yang justru mengesampingkan asas legalitas dan lebih mengutamakan efisiensi (doelmatigheid).

Saat ini mekanisme yuridis begitu dominan digunakan dalam rangka reformasi birokrasi yang ditandai dengan dilakukannya formalisasi terhadap Asasasas Umum Pemerintahan Yang Baik, yang pada awalnya merupakan code of ethic ke dalam peraturan perundang-undangan. Hal ini terlihat dengan pembentukan beberapa regulasi di bidang ini, seperti UU Pelayanan Publik, dan penyusunan RUU Administrasi Pemerintahan. Namun demikian perlu dijaga agar jangan sampai regulasi ini berimbas pada terjadinya kriminalisasi perbuatan administrasi yang dilakukan oleh pejabat administrasi (birokrat). Salah satu hal yang menyebabkannya adalah makin terkikisnya ruang diskresi sebagai akibat menguatnya

Sjachran Basah, Perlindungan Hukum terhadap Sikap Tindak Administrasi Negara, (Bandung: Alumni, 1992), hal. 6. 
ketidakpercayaan terhadap code of live selain peraturan perundang-undangan tertulis.

Perlu diingat bahwa diskresi muncul karena adanya tujuan kehidupan bernegara yang harus dicapai, tujuan bernegara dari faham negara kesejahteraan adalah untuk menciptakan kesejahteraan rakyat. Tidak dapat dipungkiri bahwa negara Indonesia pun merupakan bentuk negara kesejahteraan modern yang tercermin dalam pembukaan UUD 1945. Dalam paragraf keempat dari pembukaan UUD 1945 tersebut tergambarkan secara tegas tujuan bernegara yang hendak dicapai. Hal tersebut mengakibatkan pemerintah harus aktif berperan mencampuri bidang kehidupan sosial-ekonomi masyarakat (public service) yang mengakibatkan administrasi negara tidak boleh menolak untuk mengambil keputusan ataupun bertindak dengan dalih ketiadaan peraturan perundang-undangan (rechtsvacuum). Oleh karena itu untuk adanya keleluasaan bergerak, diberikan kepada administrasi negara (pemerintah) suatu kebebasan bertindak yang seringkali juga disebut freies ermessen sepanjang tidak ada penyalahgunaan kewenangan (detournament de povoir).

Di dalam menjalankan pemerintahan, Pemerintah telah dilengkapi dengan kewenangan-kewenangan baik yang bersifat atributif maupun yang bersifat delegatif.
Dengan adanya perkembangan masyarakat, maka seringkali terdapat keadaan-keadaan tertentu/mendesak yang membuat Pajabat/ Badan administrasi pemerintahan tidak dapat menggunakan kewenangannya khususnya kewenangan yang bersifat terikat (gebonden bevoegheid), dalam melakukan tindakan hukum dan tindakan faktual secara normal.

Sebagai negara yang bertujuan untuk memajukankesejahteraanumum, melekatnya fungsi memajukan kesejahteraan umum dalam welfare state (negara kesejahteraan) menimbulkan beberapa konsekuensi terhadap penyelenggaraan pemerintahan yaitu pemerintah harus berperan aktif mencampuri bidang kehidupan sosial ekonomi masyarakat. Untuk itu kepada pemerintah dilimpahkan bestuurszorg atau public service. Agar servis publik dapat dilaksanakan dan mencapai hasil maksimal, kepada administrasi negara diberikan suatu kemerdekaan tertentu untuk bertindak atas inisiatif sendiri menyelesaikan berbagai permasalahan pelik yang membutuhkan penanganan secara cepat, sementara terhadap permasalahan itu tidak ada, atau masih belum dibentuk suatu dasar hukum penyelesaiannya oleh lembaga legislatif ${ }^{8}$ yang kemudian dalam hukum administrasi negara diberikan kewenangan bebas berupa diskresi.

Patuan Sinaga, Hubungan antara kekuasaan dengan Pouvoir Discretionnaire Dalam Penyelenggaraan Pemerintahan dalam SF Marbun dkk, Dimensi-Dimensi Pemikiran Hukum Administrasi Negara, (Yogyakarta: UII Press, 2001) hal. 73 . 
SF Marbun ${ }^{9}$ mengatakan bahwa dengan diberikannya kebebasan bertindak (freies ermessen) kepada administrasi negara dalam melaksanakan tugasnya mewujudkan welfare state atau social rechtsstaat di Belanda sempat menimbulkan kekhawatiran bahwa akibat darifreies ermessen akan menimbulkan kerugian bagi warga masyarakat. Oleh karena itu untuk meningkatkan perlindungan hukum bagi warga masyarakat, tahun 1950 Panitia de Monchy di Netherland membuat laporan tentang asas-asas umum pemerintahan yang baik atau algemene beginselen van behoorlijk bestuur. Pada mulanya timbul keberatan dari pejabat-pejabat dan pegawai-pegawai pemerintah di Netherland karena ada kekhawatiran bahwa Hakim atau Pengadilan Administrasi kelak akan mempergunakan istilah itu untuk memberikan penilaian terhadap kebijaksanaan-kebijaksanaan yang diambil pemerintah, namun keberatan demikian sekarang ini telah lenyap ditelan masa karena telah hilang relevansinya.

\section{B. Permasalahan}

Dari uraian di atas, dirumuskan beberapa permasalahan sebagai berikut:
1. Mengapa diskresi diperlukan dalam hukum administrasi?

2. Upaya apa yang bisa dilakukan untuk mereformulasi diskresi dalam penataan hukum administrasi?

\section{Metode Penelitian}

Berdasarkan identifikasi masalah sebagaimana diuraikan di atas, maka tulisan ini masuk dalam penelitian hukum yang normatif, untukitutulisan inimempergunakan metode penelitian juridis normatif. ${ }^{10}$

Dengan metode yuridis normatif dimaksudkan untuk menjelaskan berbagai peraturan perundang-undangan yang terkait dengan hukum administrasi.

Penelitian ini juga menggunakan pendekatan sosio hukum, dengan maksud ingin melihat lebih jauh daripada sekedar pendekatan doktrinal, sehingga memiliki perspektif lebih luas dengan melihat hukum administrasi negara dalam hubungannya dengan sistem sosial, politik, dan ekonomi masyarakat. ${ }^{11}$

9 SF Marbun, Menggali dan Menemukan Asas-asas Umum Pemerintahan yang Baik Di Indonesia, dalam SF Marbun dkk, Dimensi-Dimensi Pemikiran Hukum Administrasi Negara, (Yogyakarta: UII Press, 2001), hal. 205.

10 Soerjono Soekanto dan Sri Mamuji, Penelitian Hukum Normatif, Suatu Tinjauan Singkat, (Jakarta: CV. Rajawali, 1990), hal. 15. Penelitian normatif adalah penelitian yang dilakukan dengan cara meneliti bahan pustaka atau data sekunder belaka. Pemikiran normatif didasarkan pada penelitian yang mencakup (1) asas-asas hukum, (2) sistematik hukum, (3) taraf sinkronisasi vertikal dan horisontal, (4) perbandingan hukum, (5) sejarah hukum. Lebih jauh tentang ini lihat Soerjono Soekanto dan Sri Mamudji, Penelitian Hukum Normatif: Suatu Tinjauan Singkat, edisi 1, cet. v, (Jakarta: PT Raja Grafindo Persada, 2001), hal. 13-14. Lihat juga Soerjono Soekanto dan Sri Mamudji, Peranan dan Penggunaan Perpustakaan di Dalam Penelitian Hukum, (Jakarta: Pusat Dokumentasi Hukum Fakultas Hukum Universitas Indonesia, 1979), hal. 15.

11 Reformasi Hukum di Indonesia, Hasil Studi Perkembangan Hukum, Proyek Bank Dunia (Jakarta: Cyberconsult, 1999) hal. 153. 


\section{Pembahasan}

\section{Diskresi Dalam Hukum Administrasi}

Menurut Kamus Hukum, ${ }^{12}$ diskresi berarti kebebasanmengambilkeputusandalamsetiap situasi yang dihadapi menurut pendapatnya sendiri. Sedangkan menurut hukum yang di cita-citakan (ius constituendum). Konsepsi ini berbeda dengan Rancangan UndangUndang Administrasi Pemerintahan Draft bulan Juli 2008, di mana dalam Pasal 6 mengartikan diskresi sebagai wewenang badan atau pejabat pemerintahan dan atau badan hukum lainnya yang memungkinkan untuk melakukan pilihan dalam mengambil tindakan hukum dan atau tindakan faktual dalam administrasi pemerintahan.

Selain itu, terdapat beberapa pakar hukum yang memberikan definisi diskresi secara bervariasi. Di antaranya adalah Indroharto, Sjachran Basah, Diana Halim Koentjoro, Esmi Warassih, dan S. Prajudi Atmosudirjo. Indroharto menyebut wewenang diskresi sebagai wewenang fakultatif, yaitu wewenang yang tidak mewajibkan badan atau pejabat tata usaha negara menerapkan wewenangnya, tetapi memberikan pilihan sekalipun hanya dalam hal-hal tertentu sebagaimana ditentukan dalam peraturan dasarnya. ${ }^{13}$ Selanjutnya
Sjachran Basah mengatakan bahwa freies ermessen adalah kebebasan untuk bertindak atas inisiatif sendiri, akan tetapi dalam pelaksanaannya haruslah tindakan-tindakan administrasi negara itu sesuai dengan hukum, sebagaimana telah ditetapkan dalam negara hukum berdasarkan Pancasila. ${ }^{14}$ Sedangkan Diana Halim Koentjoro mengartikan freies ermessen sebagai kemerdekaan bertindak administrasi negara atau pemerintah (eksekutif) untuk menyelesaikan masalah yang timbul dalam keadaan kegentingan yang memaksa, dimana peraturan penyelesaian untuk masalah itu belum ada. ${ }^{15}$ Lebih lanjut Esmi Warassih mengatakan bahwa dalam rangkapelaksanaankebijaksanaanpublik, para birokrat dapat menentukan kebijaksanaannya sendiri untuk menyesuaikan dengan situasi dimana mereka berada, terutama yang berkaitan dengan ketersediaan sumber daya seperti informasi, dana, tenaga ahli, tenaga-tenaga terampil maupun mengenai pengetahuan yang mereka miliki. Itu berarti, diskresi merupakan fenomena yang amat penting dan fundamental, terutama di dalam mengimplementasikan suatu kebijaksanaan publik. Dengan adanya diskresi ini diharapkan agar dengan kondisi yang ada dapat dicapai suatu hasil atau tujuan yang maksimal. ${ }^{16}$

12 JCT Simorangkir dkk,Kamus Hukum, Penerbit Sinar Grafika, Jakarta, 2008, hal. 38.

13 Indroharto, Usaha memahami Undang-Undang Tentang Peradilan Tata Usaha Negara, Buku I, Sinar Harapan, Jakarta, 1993, hal. 99-101.

14 Sjachran Basah, Eksistensi dan Tolok Ukur Peradilan Administrasi Negara di Indonesia, (Bandung: Alumni, 1997), hal. 3.

15 Diana Halim Koentjoro, Hukum Administrasi Negara, (Bogor: Ghalia Indonesia, 2004), hal. 41.

16 Esmi Warassih, Pranata Hukum Sebuah Telaah Sosiologis, (Semarang: PT. Suryandaru Utama, 2005), hal. 138139. 
S. Prajudi Atmosudirjo ${ }^{17}$ mendefinisikan diskresi, discretion (Inggris), discretionair (Perancis), freies ermessen (Jerman) sebagai kebebasan bertindak atau mengambil keputusan dari para pejabat administrasi negara yang berwenang dan berwajib menurut pendapat sendiri. Selanjutnya dijelaskannya bahwa diskresi diperlukan sebagai pelengkap dari asas legalitas, yaitu asas hukum yang menyatakan bahwa setiap tindak atau perbuatan administrasi negara harus berdasarkan ketentuan UndangUndang. Akan tetapi tidak mungkin bagi undang-undang untuk mengatur segala macam kasus posisi dalam praktek kehidupan sehari-hari. Dengan kesadaran semacam ini maka kemudian populer sebuah prinsip perundang-undangan yang mengatakan bahwa "there is no rule without exception". Oleh sebab itu perlu adanya kebebasan atau diskresi dari administrasi negara yang terdiri atas diskresi bebas dan diskresi terikat.

Pada diskresi bebas, Undang-Undang hanya menetapkan batas-batas dan administrasi negara bebas mengambil keputusan apa saja asalkan tidak melampaui/ melanggar batas-batas tersebut, sedangkan pada diskresi terikat, Undang-Undang menetapkan beberapa alternatif keputusan dan administrasi negara bebas memilih salah satu alternatif keputusan yang disediakan oleh undang-undang.
Contoh konkrit dari diskresi terikat adalah ketentuan mengenai hukuman disiplin berat bagi Pegawai Negeri Sipil berupa pemberhentian sebagaimana diatur dalam Pasal 8 huruf b Peraturan Pemerintah Nomor 32 Tahun 1979 tentang Pemberhentian Pegawai Negeri Sipil, yaitu dalam hal pemberhentian karena dihukum penjara berdasarkan putusan pengadilan yang telah mempunyai kekuatan hukum tetap, karena dengan sengaja melakukan suatu tindak pidana kejahatan yang diancam dengan pidana penjara setinggi-tingginya 4 (empat) tahun, atau diancam dengan pidana yang lebih berat. Di dalam penjelasannya disebutkan bahwa pemberhentian sebagaimana dimaksud dalam pasal ini dapat dilakukan dengan hormat atau tidak dengan hormat, satu dan lain hal tergantung pada pertimbangan pejabat yang berwenang atas berat atau ringannya perbuatan yang dilakukan dan besar atau kecilnya akibat yang ditimbulkan oleh perbuatan itu.

Meskipun maksimum ancaman pidana terhadap suatu tindak pidana telah ditetapkan, namun pidana yang dijatuhkan/ diputuskan oleh Hakim terhadap jenis tindak pidana itu dapat berbeda-beda sehubungan dengan berat ringannya tindak pidana yang dilakukan dan atau besar kecilnya akibat yang ditimbulkannya. Berhubung dengan itu, maka dalam mempertimbangkan

17 S. Prajudi Atmosudirjo, Hukum Administrasi Negara, (Jakarta: Ghalia Indonesia, 1994), hal. 82. 
apakah Pegawai Negeri Sipil yang telah melakukan tindak pidana kejahatan itu akan diberhentikan atau tidak atau apakah akan diberhentikan dengan hormat ataukah tidak dengan hormat haruslah dipertimbangkan faktor-faktor yang mendorong Pegawai Negeri Sipil yang bersangkutan melakukan tindak pidana kejahatan itu, serta harus pula dipertimbangkan berat ringannya putusan pengadilan yang dijatuhkan.

Dalam hal ini, pejabat yang berwenang menjatuhkan hukuman disiplin berat dapat menentukan sendiri hukuman disiplin berat yang akan dijatuhkannya apakah berupa pemberhentian dengan hormat tidak atas permintaan sendiri ataukah pemberhentian tidak dengan hormat tergantung penilaiannya mengenai berat ringannya pelanggaran yang dilakukan oleh Pegawai Negeri Sipil sehingga apakah Pegawai Negeri Sipil yang bersangkutan pantas dijatuhi hukuman disiplin pemberhentian dengan hormat tidak atas permintaan sendiri ataukah pemberhentian tidak dengan hormat merupakan diskresi yang terikat. Mengenai contoh kasusnya akan diuraikan didalam bagian hasil penelitian dan pembahasan.

Bila menoleh kembalike belakang, secara teoritis diskresi merupakan jalan keluar yang diberikan atas berbagai kelemahan aliran legisme yang melahirkan asas legalitas.
Asas legalitas sebenarnya hanya dianut oleh rezim hukum pidana. Hukum Administrasi tidak mengikuti asas ini. Tetapi pesinggungan kedua rezim hukum ini terjadi ketika terjadi perbuatan melawan hukum yang dilakukan oleh pejabat negara. Sebagai contoh, dalam UU No. 31 Tahun 1999 tentang Pemberantasan Tindak Pidana Korupsi (UU TPK) yang kemudian diubah dengan UU No. 20 Tahun 2001. Di sini terlihat bahwa perbuatan administrasi negara telah mengalami kriminalisasi dengan merumuskan bahwa ".......secara melawan hukum melakukan perbuatan memperkaya diri sendiri atau orang lain atau suatu korporasi yang dapat merugikan keuangan negara atau perekonomian negara,...18. Serta “..... menyalahgunakan kewenangan, kesempatan atau sarana yang ada padanya karena jabatan atau kedudukan yang dapat merugikan keuangan negara atau perekonomian negara....".

Penggunaan istilah "dapat" di dalam UU TPK bisa dimaknai bahwa perbuatanperbuatan yang berpotensi merugikan keuangan negara atau perekonomian negara merupakan perbuatan pidana meski kerugian negara tersebut belum terjadi. Hal ini merupakan celah multiinterpretasi yang justru "menggoda" oknum-oknum pengawas dan penegak hukum untuk melakukan

Selengkapnya baca pasal 2 ayat (1) Undang-Undang No. 31 Tahun 1999. Pasal ini pernah diajukan judicial review oleh Ir.Dawud Djatmiko pada 2006 dalam perkara Nomor : 003/PUU-IV/2005, tetapi hal terkait kata-kata "dapat" justru tidak mendapatkan perhatian dari Mahkamah Konstitusi. Bandingkan dengan http: //www.transparansi. or.id/ artikel/ pemberantasan-korupsi-tak-sebatas-legalitas/ 
penyalahgunaan kewenangan (detournament de povoir). Bahkan terdapat kecenderungan untuk mengadili secara pidana sebuah produk kebijakan yang dikeluarkan oleh pejabat negara yang seharusnya diadili secara Tata Negara (lewat mekanisme Judicial Review atau Executive review) atau secara Tata Usaha Negara.

Selain itu, perumusan pasal ini juga masih terlalu menitikberatkan pada unsur kerugian negara, sementara pertimbangan bahwa perbuatan tersebut merupakan diskresi yang bermanfaat bagi kepentingan umum atau tidak kurang diperhatikan. Hal ini menimbulkan ketakutan aparat birokrasi sehingga tidak berani menjalankan tugasnya karena tidak ada ruang sama sekali melakukan freies ermessen.

Diskresi lahir dari aliran Rechtsvinding yang menyadari bahwa pembuat undangundang tidak dapat mengikuti kecepatan gerak masyarakat atau proses perkembangan sosial yang sangat dinamis, sehinggga undang-undang selalu ketinggalan. Undangundang tidak dapat lengkap dan tidak dapat mencakup segala-galanya. $\mathrm{Di}$ sini selalu ada leemten (kekosongan dalam undangundang), sehingga harus dipahami dengan jalan mengadakan rekonstruksi hukum.

Marcus Lukman sebagaimana dikutip oleh Saut P Panjaitan ${ }^{19}$ mengatakan bahwa persoalan-persoalan penting yang mendesak, sehingga memerlukan diskresi, sekurangkurangnya mengandung unsur-unsur sebagai berikut :

a. Persoalan-persoalan yang muncul harus menyangkut kepentingan umum, yaitu: kepentingan bangsa dan negara, kepentingan masyarakat luas, kepentingan rakyat banyak/bersama, serta kepentingan pembangunan.

b. Munculnya persoalan tersebut secara tiba-tiba, berada di luar rencana yang telah ditentukan.

d. Untukmenyelesaikan persoalantersebut, peraturan perundang-undangan belum mengaturnya atau hanya mengatur secara umum, sehingga administrasi negara mempunyai kebebasan untuk menyelesaikan atas inisiatif sendiri.

e. Prosedurnya tidak dapat diselesaikan menurut administrasi yang normal, atau jika diselesaikan menurut prosedur administrasi yang normal justru kurang berdaya guna dan berhasil guna.

f. Jika persoalan tersebut tidak diselesaikan dengan cepat, maka akan menimbulkan kerugian bagi kepentingan umum.

Dengan adanya freies ermessen ini berarti bahwa sebagian kekuasaan yang dipegang oleh badan pembentuk undangundang dipindahkan ke dalam tangan pemerintah/administrasi negara, sebagai 
badan eksekutif. Hal ini bukan berarti bahwa terjadi pergeseran supremasi badan legislatif diganti oleh supremasi badan eksekutif ${ }^{20}$, karena dianggap administrasi negara telah melakukan penyelesaian masalah tanpa harus menunggu perubahan UndangUndang dari bidang legislatif ${ }^{21}$, tetapi hal tersebut terjadi karena pada prinsipnya Badan/Pejabat administrasi pemerintahan tidak boleh menolak untuk memberikan pelayanan kepada masyarakat dengan alasan hukumnya tidak ada ataupun hukumnya ada tetapi tidak jelas, sepanjang hal tersebut masih menjadi kewenangannya.

Dalam perkembangannya, diskresi ini lebih banyak dibicarakan dalam hukum administrasi. Hukum Administrasi (Negara) biasa disebut juga dengan Hukum Tata Usaha Negara atau Hukum Tata Pemerintahan. Lingkup Pemerintahan ${ }^{22}$ dalam Hukum Administrasi, adalah berada pada lingkungan jabatan di luar kekuasaan Legislatif, Yudikatif, dan kekuasaan yang dijalankan MPR, dan BPK. Lingkup Pemerintahan tersebut juga tidak termasuk kekuasaan Presiden yang bersifat Kenegaraan (staatrechtelijk), sebagai penyelenggara negara. Pemerintahan dalam uraian ini semata-mata diartikan sebagai lingkungan jabatan administrasi negara atas yang dalam bahasa ilmu administrasi negara (Public Administration), disebut birokrasi (beauraucracy) atas bestur (Bestuur).

Secara keilmuan banyak definisi tentang hukum administrasi yang dikemukakan para sarjana. ${ }^{23}$ Dari sekian banyak definisi yang ada, inti "hukum administrasi" adalah keseluruhan peraturan yang berkaitan dengan penyelenggaraan pemerintahan (het geheel van regels betreffende het besturen) dan yang menyatakan hubungan hukum (rechtsbetrekking) pemerintah dengan warga negara.

Hukum administrasi terdiri dari dua bagian, yaitu bagian khusus dan bagian umum. Pada bagian khusus (bijzonder deel) yakni hukum-hukum yang terkait dengan bidang-bidang pemerintahan tertentu seperti hukum lingkungan, hukum tata ruang, hukum kesehatan, hukum perpajakan, hukum cukai, hukum yang bersifat sektoral, dan lain-lain. Sedangkan bidang umum (algemeen deel), yakni berkenaan dengan teori-teori dan prinsip-prinsip yang berlaku untuk semua bidang hukum administrasi. ${ }^{24}$

Jika dipetakan lebih jauh, hingga saat ini, Peraturan perundang-undangan di bidang hukum administrasi masih bersifat sektoral dan bahkan ada yang tidak normatif.

20 Bandingkan dengan A. Siti Soetami, Hukum Administrasi Negara, (Semarang: Badan Penerbit Universitas Diponegoro, 2000), hal. 46.

21 Bandingkan dengan Diana Halim Koentjoro, Hukum Administrasi Negara, (Bogor: Ghalia Indonesia, 2004), hal. 42.

22 Bagir Manan, “Orasi pada Seminar RUU Administrasi Pemerintahan se - Sumatera di Medan ” 29 Juni 2005.

3 Marbun, "Makalah pada seminar Indonesia - Jerman - RUU tentang Administrasi Pemerintahan, di Jakarta, 5 April 2005.

24 Ibid. 
Peraturan Perundang-undangan Hukum Administrasi di Indonesia yang masih sektoral, (bijzondere bestuurswetten) mengakibatkan: ${ }^{25}$ Pertama, tidak ada standard baku menyangkut istilah di bidang hukum administrasi, asas maupun /konsep. contoh: "keputusan tata usaha negara" dijumbuhkan dengan "keputusan administratif", atau "melampaui kewenangan" dijumbuhkan dengan "penyalahgunaan wewenang". Kedua, tidak terdapat sinkronisasi asas hukum administrasi. contoh: asas praesumptio iustae causa (vermoeden van rechtmatigheid) tidak diikuti oleh sebagian besar peraturan perundang-undangan sektoral. Ketiga, tidak terdapat pemahaman yang sama menyangkut konsep-konsep dalam hukum administrasi. Misal: diskresi dijumbuhkan dengan melanggar undangundang, penyalahgunaan wewenang dijumbuhkan dengan penyalahgunaan sarana dan kesempatan, serta penggunaan delegasi dan mandat secara salah. ${ }^{26}$ Kondisi demikian sangat berpengaruh bagi public service, penegakan hukum, perlindungan hukum bagi rakyat, dan usaha pemberantasan korupsi.

Perbaikan-perbaikan dan penyempurnaan di bidang administrasi pemerintahan yang perlu dilakukan adalah bersifat menyeluruh. Namun ada hal-hal yang segera perlu dilakukan, terutama untuk menjamin kelancaran perencanaan dan pelaksanaan pembangunan. Dengan demikian, perbaikan administrasi pemerintahan perlu dilakukan secara bertahap menurut prioritas-prioritasnya.

Salah satu upaya yang bisa dilakukan untuk menyempurnakan HAN yang telah ada tersebut adalah dengan melakukan Kodifikasi HukumAdministrasi.Dalamrangkamelakukan Kodifikasi Hukum Administrasi Umum, terdapat 3 (tiga) komponen dasar hukum administrasi yang perlu diperhatikan, yaitu: ${ }^{27}$ Pertama, hukum untuk penyelenggaraan pemerintahan (het recht voor het besturen door de overdheid; recht voor het bestuur: normering van het bestuursoptreden). Kedua, hukum oleh pemerintah (het recht dat uit dit bestuur onstaat; recht van het bestuur: nadere regelgeving, beleidsregels, concrete bestuursbes/uiten). Ketiga, hukum terhadap pemerintah yaitu hukum yang menyangkut perlindungan hukum bagi rakyat terhadap tindakan pemerintahan (het recht tegen het bestuur).

Diskresi merupakan bagian utama dari hukum administasi dalam rangka penyelenggaraan pemerintah. Selain diskresi ini, beberapa bagian utama lain dalam penyelenggaraan pemerintah adalah: sumber wewenang: atribusi, delegasi dan mandat; Asas penyelenggaraan pemerintahan. Berdasarkan asas negara

Philipus M. Hadjon, RUU Administrasi Pemerintahan Dalam Pembangunan Hukum Administrasi, diakses dari http:// dialektikahukum.blogspot.com /2009/02/ruu-administrasi-pemerintahan-dalam.html.

26 Ibid.

27 Ibid. 
hukum, asas dasar adalah asas legalitas (rechtmatigheid van bestuur); dan prosedur penggunaan wewenang.

\section{Reformulasi Diskresi dan Penataan HAN}

Salah satu agenda penataan HAN adalah pembentukan UU tentang Administrasi Pemerintahaan yang hingga saat ini masih dibahas. Dalam rangka pembentukan UU tersebut, perlu dilakukan juga harmonisasi terhadap peraturan perundang-undangan yang lain. Salah satu yang paling penting adalah harmonisasi antara RUU Administrasi Pemerintahan dengan UU Peradilan Tata Usaha Negara serta UU Pemberantasan Korupsi agar diskresi bisa dimasukkan sebagai bagian yang penting.

Harmonisasi hubungan Rancangan Undang-undang tentang Administrasi Pemerintahan dengan Undang-undang tentang Peradilan Tata Usaha Negara, terlihat secara jelas dalam pandangan dari Paulus Effendi Lotulung ${ }^{28}$ yang menyatakan bahwa Undang-undang Peradilan Tata Usaha Negara lebih banyak menekankan pada hukum acara atau prosedur di peradilan, sehingga lebih banyak bersifat hukum prosedural (Formal), yang berlaku bagi badan peradilan (hal mana memang formal karena ditujukan untuk suatu badan peradilan). Di sisi lainnya tidak banyak ketentuan hukum materil (substansial) yang dimuat di dalamnya dan itu pun tidak secara lengkap atau jelas dijabarkan, sehingga berpotensi menimbulkan multi interpretasi diantara para hakim sesamanya apalagi para penyelenggara administrasi negara. Hal senada dikemukakan oleh A.A. Oka Mahendra ${ }^{29}$ yang melihat bahwa RUU Administrasi Pemerintahan secara umum perlu mengatur hukum materil penyelenggaraan administrasi pemerintahan atau mengatur syarat-syarat dan tata cara pembuatan keputusan Tata Usaha Negara yang dapat dijadikan landasan yuridis untuk menilai prosedur dan materi muatan keputusan Tata Usaha Negara sesuai atau tidak dengan Undang-undang dan asas-asas umum pemerintahan yang baik.

Dalam melakukan harmonisasi tersebut, perlu dipahami bahwa penataan HAN ke depanperlumemperhatikanfungsidantujuan dari kegiatan pemerintahan itu sendiri. Hal ini penting untuk bisa menempatkan posisi diskresi dalam penyelenggaraan negara, sebagaimana yang diungkapkan Talizidhuhu Ndraha ${ }^{30}$ yang menyebutkan bahwa kegiatan pemerintahan harus sesuai dengan tujuan lembaga yang bersangkutan (pemerintah) yang telah ditetapkan. Menurut Ryaas

28 Paulus Effendi Lotulung,, Makalah pada seminar Indonesia-Jerman, Tinjauan Umum atas Rancangan UndangUndang Administrasi Pemerintahan, Jakarta, 5 April 2005.

29 AA. Oka Mahendra, "Harmonisasi RUU Administrasi Pemerintahan dengan Undang-Undang Peradilan TUN dan Undang-Undang lainnya”, Makalah pada Seminar Nasional RUU Administrasi Pemerintahan, Jakarta, 13 Oktober 2005.

30 Talizidhuhu Ndraha, Makalah pada Semiloka I, Kajian Reformasi Hukum Administrasi Pemerintahan, "Fungsi Pemerintahan", Jakarta, 27 April 2004. 
Rasyid $^{31}$ ada tiga fungsi hakiki Pemerintahan, yaitu Pelayanan (service), pemberdayaan (Empowerment) dan pembangunan (development).

Dengan pemahaman itu, Rancangan Undang-undang Administrasi Pemerintahan, merumuskan pengertian "Administrasi Pemerintahan" adalah tatalaksana dalam mengambil tindakan hukum dan atau tindakan faktual badan atau pejabat pemerintahan. Rancangan Undang-Undang Administrasi Pemerintahan Draft bulan Juli 2008 dalam Pasal 6 ayat (1) memberi batasan terhadap diskresi dengan menyebutkan bahwa Pejabat pemerintahan dan atau badan hukum lainnya yang menggunakan diskresi dalam mengambil keputusan wajib mempertimbangkan tujuan diskresi, peraturan perundang-undangan yang menjadi dasar diskresi dan asas-asas umum pemerintahan yang baik. Selanjutnya ayat (2) dan ayat (3) menyebutkan bahwa penggunaan diskresi wajib dipertanggungjawabkan kepada pejabat atasannya dan masyarakat yang dirugikan akibat keputusan diskresi yang telah diambil serta dapat diuji melalui upaya administratif atau gugatan di Peradilan Tata Usaha Negara.

Ketentuan tersebut berarti bahwa Rancangan Undang-Undang Administrasi
Pemerintahan bukan hanya akan memberi batas-batas penggunaan diskresi oleh Badan/Pejabat administrasi Pemerintahan, akan tetapi juga mengatur mengenai pertanggung-jawaban Badan/Pejabat Administrasi Pemerintahan terhadap penggunaan diskresi yang tidak hanya bersifat pasif dalam arti menunggu adanya gugatan dari masyarakat melalui Pengadilan Tata Usaha Negara akan tetapi juga bersifat aktif dengan adanya kewajiban mempertanggungjawabkan penggunaan diskresi kepada Pejabat atasannya mengingat hal tersebut merupakan suatu kewajiban yang sifatnya melekat pada kewenangan yang menjadi dasar adanya diskresi itu sendiri32 dan di dalam penjelasannya disebutkan bahwa pertanggungjawaban kepada atasan dilaksanakan dalam bentuk tertulis dengan memberikan alasan-alasan pengambilan keputusan diskresi.

Tetapiyang disayangkan adalah meskipun Pasal 6 RUU Administrasi Pemerintahan telah mengatur tentang kewajiban melaporkan tindakan diskresi kepada atasan dalam bentuk tertulis dengan memberikan alasanalasan pengambilan keputusan diskresi, namun apabila ketentuan tersebut tidak dilaksanakan tidak ada sanksinya sehingga hal tersebut dapat menyebabkan Badan/Pejabat

Ryaas Rasyid, Makna Pemerintahan : Tinjauan dari Segi Etika dan Kepemimpinan, (Jakarta : P.T. Yarsif Watampone, 1997), hal. 11-12

32 Rusma Dwiyana, Akuntabilitas Administrasi dan Hukum Atas Keputusan Administrasi Pejabat Pemerintahan, diunduh dari www.wordpress.com, Januari 2009. 


\section{$\mathrm{R}^{\text {juenal }}$ ECHSVINDING}

AdministrasiPemerintahan yang menerbitkan keputusan diskresi berdalih bahwa keputusan yang diambilnya bukan keputusan diskresi ataupun berdalih ia tidak tahu bahwa keputusan yang diambilnya adalah keputusan diskresi. Walaupun demikian paling tidak dengan akan dijadikannya batas-batas penggunaan diskresi sebagai suatu norma yang mengikat, maka hal tersebut sudah cukup untuk menghindari dilaksanakannya penyalahgunaan wewenang (detournement de pouvoir) dan perbuatan sewenangwenang (willekeur) oleh Badan/Pejabat Administrasi Pemerintahan, sebab tujuan utama dari normatifisasi adalah menciptakan dan menjadikan Hukum Administrasi Negara menunjang kepastian hukum yang memberi jaminan dan perlindungan hukum, baik bagi warga negara maupun administrasi negara. ${ }^{33}$

Penggunaan freies ermessen oleh Badan/ Pejabat administrasi negara dimaksudkan untuk menyelesaikan persoalan-persoalan penting dan mendesak serta tiba-tiba yang sifatnya kumulatif. Bisa saja muncul persoalan yang penting tapi tidak mendesak untuk segera diselesaikan. Ada pula kemungkinan muncul persoalan mendesak, tapi tidak terlalu penting untuk diselesaikan. Suatu persoalan baru dapat dikualifikasi sebagai persoalan penting apabila persoalan tersebut menyangkut kepentingan umum, sedangkan kriteria kepentingan umum harus ditetapkan oleh suatu peraturan perundang-undangan.

Berdasarkan hal tersebut di atas, dapat disimpulkan bahwapenggunaankewenangan diskresi oleh Badan/Pejabat administrasi pemerintahan hanya dapat dilakukan dalam hal tertentu dimana peraturan perundangundangan yang berlaku tidak mengaturnya atau karena peraturan yang ada yang mengatur tentang sesuatu hal tidak jelas dan hal tersebut dilakukan dalam keadaan darurat/mendesak demi kepentingan umum yang telah ditetapkan dalam suatu peraturan perundang-undangan.

Dalam perkembangannya, Rancangan Undang-Undang Administrasi Pemerintahan akan memperluas kewenangan absolut Pengadilan Tata Usaha Negara melalui Pasal 44 yang menyebutkan bahwa kewenangan untuk memeriksa dan memutus perkara yang berkaitan dengan tindakan badan atau pejabat pemerintahan dan atau badan hukum lainnya yang menimbulkan kerugian material maupun immaterial dilaksanakan oleh Pengadilan Tata Usaha Negara.

Dengan adanya tambahan kewenangan untuk menguji perkara-perkara yang berkaitan dengan tindakan badan atau pejabat pemerintahan dan atau badan hukum lainnya yang menimbulkan kerugian material maupun immaterial, maka semakin lengkap fungsi Pengadilan Tata Usaha Negara sebagai fungsi kontrol yuridis terhadap pemerintah.

33 Rusli K. Iskandar, Normatifisasi Hukum Administrasi Negara, dalam SF Marbun dkk, Dimensi-Dimensi Pemikiran Hukum Administrasi Negara, (Yogyakarta: UII Press, 2001), hal. 187. 
Lintong Oloan Siahaan ${ }^{34}$ mengatakan bahwa Pemerintah sebagai pelayan (public service) mempunyai kekuasaan (power) untuk melaksanakan tugas pelayanannya tadi, yang apabila disalahgunakan akan menjadi fatal akibatnya dari segi hukum. Untuk itu perlu adanya kontrol, yang dengan demikian kemungkinan akan adanya penyalahgunaan kekuasaan, kesewenang-wenangan dan lain-lain dapat dihindari atau diperkecil kemungkinan. Kontrol yuridis merupakan bagian dari kontrol lain-lainnya terhadap pemerintah seperti kontrol politis, kontrol melalui tromol-tromol pos, kontrol intern administrasi, kontrol ekstern organisasi/ lembaga baik yang struktural maupun non struktural. ${ }^{35}$

Kontrol ekstern yang berbentuk organisasi/lembaga yang bersifat struktural sudah diaturdidalam Undang-Undang Nomor. 37 Tahun 2008 tentang Ombudsman RI yang berwenang mengawasi penyelenggaraan pelayanan publik baik yang dilaksanakan oleh penyelenggara negara dan pemerintahan, termasuk yang diselenggarakan oleh BUMN, BUMD dan BHMN serta badan swasta atau perorangan yang diberi tugas menyelenggarakan pelayanan publik tertentu yang sebagian atau seluruh dananya bersumber dari APBN dan/atau APBD ${ }^{36}$

\section{E. Penutup}

\section{Kesimpulan}

a. Diskresi diperlukan dalam hukum administrasi dalam rangka menyelesaikan persoalan yang peraturan perundang-undangan belum mengaturnya atau hanya mengatur secara umum, sehingga administrasi negara mempunyai kebebasan untuk menyelesaikan atas inisiatif sendiri. Diskresi juga diperlukan apabila terdapat prosedur yang tidak dapat diselesaikan menurut administrasi yang normal, atau jika diselesaikan menurut prosedur administrasi yang normal justru kurang berdaya guna dan berhasil guna, atau perlu penanganan yang sangat cepat.

b. Reformulasi diskresi dalam penataan hukum administrasi sangat diperlukan meski telah ada kesepakatan secara teoritis bahwa pada dasarnya diskresi tidak bisa sembarangan dipakai. Diskresi hanya bisa dipakai pada keadaankeadaan tertentu, seperti apabila terjadi kekosongan hukum; adanya kebebasan interprestasi; adanya

34 Lintong Oloan Siahaan, Wewenang PTUN menunda berlakunya Keputusan Pemerintah, (Jakarta: Perum Percetakan Negara RI, 2006), hal. 10.

35 Lintong Oloan Siahaan, Prospek PTUN sebagai Pranata Penyelesaian Sengketa Administrasi di Indonesia, Studi Tentang Keberadaan PTUN Selama Satu Dasawarsa 1991-2001, (Jakarta: Perum Percetakan Negara RI, 2005), hal. 42-43.

36 Pasal 1 ayat (1) Undang-Undang Nomor 37 Tahun 2008 tentang Ombudsman RI. 
delegasi perundang-undangan; serta demi pemenuhan kepentingan umum. Selainitu, pembuatandiskresi juga dibatasi oleh asas-asas hukum administrasi serta asas-asas umum pemerintahan yang baik. Di antara asas-asas umum pemerintahan yang baik yang paling mendasar adalah larangan penyalahgunaan wewenang dan larangan bertindak sewenang-wenang. Tetapi euforia semangat pemberantasan korupsi melihat bahwa tanpa dituangkan dalam regulasi (baca: undang-undang) maka pagar yang membatasi kewenangan mengeluarkan diskresi pejabat negara akan mudah diterobos oleh pejabat negara. Pemikiran semacam ini dilandasi oleh pengalaman historis bahwa pada masa lalu, diskresi yang dikeluarkan oleh penyelenggara negara cenderung merugikan masyarakat dan mengeruk kekayaan negara. Padahal teori mengenai asas-asas umum pemerintahan yang baik (AUPB) yang menjadi dasar pembuatan diskresi sudah banyak, tapi dalam prakteknya tidak dijalankan oleh para pejabat. Hal inilah yang mendorong formalisasi AUPB dalam hukum positif. Teori mengenai asasasas umum pemerintahan yang baik (AUPB) telah banyak sekali berkembang. Di Belanda AUPB ini disebut Algemene Beginselen van Behoorlijk Bestuur, sementara di USA disebut "The principle of good public administration." AUPB ini pada dasarnya adalah code of ethic. Tetapi setelah lahirnya UU No. 28 Tahun 1999 tentang Penyelenggara Negara yang Bersih dan Bebas dari Korupsi, Kolusi, dan Nepotisme, (UU KKN) telah terjadi formalisasi AUPB dalam hukum positif. Formalisasi ini diadopsi juga oleh UU No.5 Tahun 1986 tentang Peradilan Tata Usaha Negara sebagaimana diubah UU No.9 Tahun 2004 dan UU No.51 Tahun 2009 yang menjadi pedoman penyelesaian sengketa Tata Usaha Negara. Formalisasi ini juga terlihat dengandisusunnyaRUUAdministrasi Pemerintahan sebagai bagian dari reformasi birokrasi. Keberadaan UU tersebut nantinya bisa menjadi batasan secara hukum pembuatan diskresi sebagai fungsi kontrol mencegah terjadinya detournament de povoir.

\section{Saran}

a. Perlu ada kesadaran dari aparan penegak hukum dan legislator bahwa kepastian bukan satusatunya tujuan hukum, masih ada keadilan dan kemanfaatan yang bisa diraih dengan mengembalikan ruang bagi code of life di luar undangundang. Undang-undang juga tidak 
dapat dibuat sangat terinci (detail)

melainkan hanya memberikan

algemeene richtlijnen (pedoman

umum) saja. Karenanya undang-

undang tidak dapat mencakup segala-galanya. Undang-undang bukan obat mujarab yang bisa menyelesaikan semua persoalan, karena ia tidak dapat mengikuti kecepatan gerak masyarakat atau proses perkembangan sosial, sehinggga undang-undang selalu ketinggalan.

b. Perlu ada kesadaran bahwa penataan Hukum Administrasi Negara bukan sekedar dipahami sebagai pembentukanatau penataan peraturan perundang-undangan terkait administrasi Negara, tetapi lebih jauh dari itu adalah penataan tatanan hukum yang terdiri dari struktur, substansi, dan kultur masyarakat, birokrasi, dan penegak hukum. 


\section{DAFTAR PUSTAKA}

Atmosudirjo, S. Prajudi, Hukum Administrasi Negara, (Jakarta: Ghalia Indonesia, 1994).

Bagir Manan, "Orasi pada Seminar RUU Administrasi Pemerintahan se - Sumatera di Medan " 29 Juni 2005.

Bank Dunia, Reformasi Hukum di Indonesia, Hasil Studi Perkembangan Hukum, (Jakarta: Cyberconsult, 1999).

Basah, Sjachran, Eksistensi dan Tolok Ukur Peradilan Administrasi Negara di Indonesia, (Bandung Alumni, 1997).

Basah, Sjachran, Perlindungan Hukum terhadap Sikap Tindak Administrasi Negara, (Bandung: Alumni, 1992).

Dwiyana, Rusma, Akuntabilitas Administrasi dan Hukum Atas Keputusan Administrasi Pejabat Pemerintahan, diunduh dari www.wordpress.com, Januari 2009.

Hadjon, Philipus M., RUU Administrasi Pemerintahan Dalam Pembangunan Hukum Administrasi, Makalah.

Harper, JH., Filsafat Politik Plato, Aristoteles, Augustinus, Machiaveli, (Jakarta: PT Raja Grafindo Persada, 2002).

Indroharto, Usaha memehami Undang-Undang Tentang Peradilan Tata Usaha Negara, Buku I, (Jakarta: Sinar Harapan, 1993).

Koentjoro, Diana Halim, Hukum Administrasi Negara, (Bogor: Ghalia Indonesia, 2004).

Lotulung, Paulus Effendi, Makalah pada seminar Indonesia-Jerman, Tinjauan Umum atas Rancangan Undang-Undang Administrasi Pemerintahan, Jakarta, 5 April 2005.

Mahendra, AA. Oka, Harmonisasi RUU Administrasi Pemerintahan dengan Undang-Undang Peradilan TUN dan Undang-Undang lainnya, Makalah pada Seminar Nasional RUU Administrasi Pemerintahan Jakarta, 13 Oktober 2005.

Marbun, SF dkk, Dimensi-Dimensi Pemikiran Hukum Administrasi Negara, (Yogyakarta: UII Press, 2001).

Marbun, SF, Makalah pada seminar Indonesia - Jerman - RUU tentang Administrasi Pemerintahan, di Jakarta, 5 April 2005.

Martosoewignjo, Sri Soemantri, Undang-Undand Dasar 1945, Kedudukan dan Artinya Dalam Kehidupan Bernegara, Makalah disampaikan pada Stadium Generale dan 40 Tahun Pengabdiannya di Universitas Padjadjaran, Bandung 2001.

Ndraha, Talizidhuhu, Makalah pada Semiloka I, Kajian Reformasi Hukum Administrasi Pemerintahan, “Fungsi Pemerintahan”, Jakarta, 27 April 2004. 
Panjaitan, Saut P., Makna dan Peranan Freies ErmessenDalam Hukum Administrasi Negara dalam

SF Marbun dkk, Dimensi-Dimensi Pemikiran Hukum Administrasi Negara, (Yogyakarta: UII Press, 2001).

Rasyid, Ryaas, Makna Pemerintahan : Tinjauan dari Segi Etika dan Kepemimpinan, 1996.

Siahaan, Lintong Oloan, Prospek PTUN sebagai Pranata Penyelesaian Sengketa Administrasi di Indonesia, Studi Tentang Keberadaan PTUN Selama Satu Dasawarsa 1991-2001, (Jakarta: Perum Percetakan Negara RI, 2005).

Siahaan, Lintong Oloan, Wewenang PTUN menunda berlakunya Keputusan Pemerintah, (Jakarta: Perum Percetakan Negara RI, 2006).

Simorangkir, JCT dkk, Kamus Hukum, (Jakarta: Penerbit Sinar Grafika, 2008).

Soekanto, Soerjono dan Sri Mamudji, Penelitian Hukum Normatif: Suatu Tinjauan Singkat, edisi 1, cet.v, (Jakarta: PT Raja Grafindo Persada, 2001).

Soekanto, Soerjono dan Sri Mamudji, Peranan dan Penggunaan Perpustakaan di Dalam Penelitian Hukum, (Jakarta: Pusat Dokumentasi Hukum Fakultas Hukum Universitas Indonesia, 1979).

Soekanto, Soerjono dan Sri Mamuji, Penelitian Hukum Normatif,_Suatu Tinjauan Singkat, (Jakarta,:

CV. Rajawali, 1990).

Soetami, A. Siti, Hukum Administrasi Negara, (Semarang: Badan Penerbit Universitas Diponegoro, 2000).

Suprianto, 2004, Syariat Islam dalam Mewujudkan "Clean Governance and Good Government" dalam www. Transparansi.or.id.

Warassih, Esmi, Pranata Hukum Sebuah Telaah Sosiologis, (Semarang: PT. Suryandaru Utama, 2005).

http://www.ppu.org.uk/people/suukyi.html

http://chandrasway.blogspot.com/2010/12/aung-san-suu-kyi-i-am-happy-because-i.html http: //www.transparansi. or.id/ artikel/ pemberantasan-korupsi-tak-sebatas-legalitas/ 